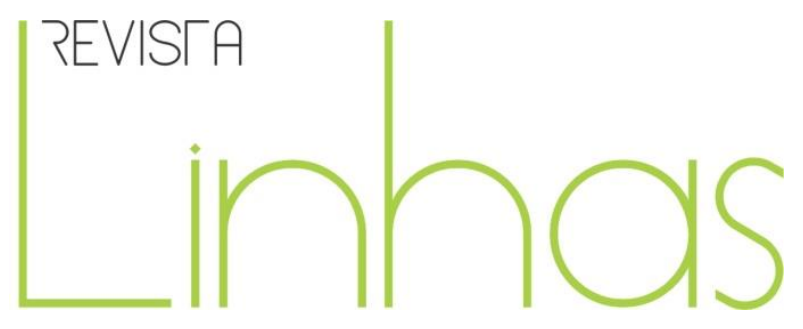

\title{
A difusão das regras de bem viver através dos gabinetes médicos e dentários entre as décadas de 1930 e 1960
}

\begin{abstract}
Resumo
O presente estudo buscou compreender a difusão das regras de bem viver por meio da criação das instituições auxiliares que desencadearam a implantação dos gabinetes médicos e dentários em quatro escolas públicas e uma privada da cidade de Porto Alegre/RS no período de 1930 a 1960. O estudo teve a pretensão de apresentar a participação dos médicos na promoção das práticas de higiene escolar introduzidas como garantia da consciência sanitária, a importância e a propagação das instituições auxiliares dentro das escolas e, por último, talvez como consequência disso, a implantação dos gabinetes médicos e dentários nas escolas. O estudo se desenvolveu por meio de pesquisa bibliográfica e análise documental, fazendo uso de entrevistas com estudantes de grupos escolares, artigos publicados na Revista do Ensino de Porto Alegre/RS no período de 1939-1960 e dos Boletins do CPOE, atas e relatórios. As análises foram qualitativas, centradas nas regras de bem viver desenvolvidas e promovidas nas instituições públicas e no educandário privado e elencadas para este estudo. Considerando os resultados das análises, podemos afirmar que os aspectos pertinentes à atuação dos médicos diante das práticas de higiene escolar, da criação das instituições auxiliares e, respectivamente, a implantação dos gabinetes médicos e dentários, foram formas de disciplinamento e de regulação de comportamentos e atingiram educadores, médicos, comunidade escolar, pais e, muito especialmente, a "nova geração dos brasileiros" e, sobretudo, validaram o intuito da renovação educacional e da identidade nacional que se constituía em um processo civilizador da nova pedagogia e da Escola Nova.
\end{abstract}

Palavras-chave: regras de bem viver; instituições auxiliares; gabinetes médicos e dentários; escolas públicas e privadas.

\author{
Alice Rigoni Jacques \\ Colégio Farroupilha - Porto \\ Alegre/RS - Brasil \\ alice_rigoni@hotmail.com
}

\footnotetext{
Para citar este artigo:

JACQUES, Alice Rigoni. A difusão das regras de bem viver através dos gabinetes médicos e dentários entre as décadas de 1930 e 1960. Revista Linhas. Florianópolis, v. 22, n. 50, p. 215-245, set./dez. 2021.
} 


\title{
The diffusion of rules of well- being through the medical and dental offices in the decade of 1930 to 1960
}

\begin{abstract}
The present study sought to understand the diffusion of the rules of well-being through the creation of the auxiliary institutions that triggered the implantation of the medical and dental offices in four public schools and a private one of the city of Porto Alegre /RS in the period from 1930 to 1960 . This study aimed to present the participation of physicians in the promotion of school hygiene practices introduced as a guarantee of sanitary awareness, the importance and propagation of auxiliary institutions within schools and, lastly, perhaps as a consequence, the implantation of medical and dental offices at Schools. The study was developed through bibliographic research and documentary analysis, using interviews with students from school groups, articles published in the Journal of Teaching of Porto Alegre / RS in the period of (19391960) and CPOE Bulletins, minutes and reports. The analysis were qualitative, focusing on the rules of wellbeing developed and promoted in the public institutions and in the private education system listed for this study. Considering the results of the analyzes, we can affirm that the aspects analyzed in this study, pertinent to the practice of the doctors in face of the practices of school hygiene, the creation of auxiliary institutions and, respectively, the implantation of the medical and dental offices, were forms of disciplining and regulating behaviors and reached educators, doctors, school community, parents and, in particular, the "new generation of Brazilians", but above all, validated the intention of educational renewal and national identity that constituted a civilizing process of the new pedagogy and New school.
\end{abstract}

Keywords: rules of well-being; auxiliary institutions; medical and dental cabinets; public and private schools. 
Educar desde a mais tenra idade, ensinar pela pedagogia do exemplo, difundir regras de bem viver, instruir para salvar da ignorância, formar atitudes e inteligência, fortalecer o caráter, restituir energias para produzir. (TOTTA, 1935, p.41)

Em meados da década de 1930, Dr. Mario Tottaํㅜ propunha as dimensões da boa educação, ensinando pela pedagogia do exemplo, mas fundamentalmente, as contribuições que a ciência médica daria para a educação, por meio das escolas que difundiriam regras de bem viver com conhecimentos científicos da medicina e com seus contributos à aprendizagem. Mario Totta (1935, p. 41) torna-se um porta-voz na difusão da atuação médica em espaços educativos, quando destaca que "as influências da escola acompanham o homem por toda vida: a escola é o destino".

Nesse viés, Stephanou (2011, p. 148) salienta que os médicos se apresentavam como uma espécie de mediadores, aqueles que, propondo medidas de ordenamento do espaço e purificação do meio, conduziriam a uma sociedade sadia e positivamente civilizada. A degeneração poderia ser contornada. A enfermidade dos corpos e da sociedade cederia lugar à saúde e à vida. Fazia-se mister, contudo, garantir espaço para a atuação educativa e saneadora da medicina.

No sentido de garantir a atuação da medicina nos espaços escolares, os médicos acabavam ocupando-se cada vez mais em discutir os conteúdos e objetos de ensino, os procedimentos pedagógicos, a avaliação, o exemplo do professor, a materialidade e a salubridade das escolas, os pressupostos teóricos dos pedagogos, e seus discursos sobre a Educação que, de acordo com Stephanou (2011), implicaram num envolvimento significativo de vários médicos em temas cada vez mais complexos sobre a escola, como os processos de aprendizagens e a educação sanitária do povo, o que permitia identificar uma intensa atuação médica em espaços educativos, seja em escolas de ensino elementar seja em escolas de ensino elementar, técnico e cursos de formação de professores.

\footnotetext{
1 Dr. Mario Totta formou-se, em 1904, médico pela Faculdade de Medicina de Porto Alegre, onde também foi professor e se aposentou em 1930. Foi diretor do gabinete de identificação do Rio Grande do Sul e fundador do Sindicato Médico do Rio Grande do Sul.
} 
Dessa forma, o presente artigo busca compreender a difusão das regras de bem viver através da implantação das instituições auxiliares por meio da criação do Pelotão de Saúde e dos gabinetes médicos e dentários entre as décadas de 1930 e 1960 em quatro escolas públicas de Porto Alegre/ RS: o Grupo Escolar Paula Soares, Grupo Escolar Uruguai, Grupo Escolar Souza Lobo e Instituto Flores da Cunha, antiga Escola Normal General Flores da Cunha, e uma instituição privada da cidade, o Colégio Farroupilha, que no período analisado teve diferentes nomes: Hindenburschule (1934), Ginásio TeutoBrasileiro Farroupilha (1936), Ginásio Farroupilha (1942) e Colégio Farroupilha (1950) até os dias de hoje.

O artigo está dividido em três tópicos, nos quais inicialmente é apresentada a participação dos médicos no desenvolvimento e conscientização das práticas da higiene escolar introduzidas como garantia da consciência sanitária que, por sua vez, manteria a ascensão do país ao status de nação culta e desenvolvida, o que asseguraria a renovação educacional. Em seguida, é discutida a criação das instituições auxiliares do ensino que surgiram agregadas à ideia de que era preciso fornecer aos alunos oportunidades favoráveis ao trabalho em comunidade e à formação de um novo sujeito, que Lourenço Filho (1969, p. 135) caracteriza como "grupos sociais da própria escola". Para ele, essas instituições auxiliares seriam as possíveis bases da nova pedagogia. O terceiro, insere-se no segundo tópico que aborda a implantação das instituições auxiliares, e diz respeito à implantação dos gabinetes médicos e dentários nas escolas, os quais estavam contemplados nos projetos arquitetônicos das novas construções dos prédios escolares, dando visibilidade a diversos aspectos da escola nova.

A partir desses três tópicos a análise do estudo pautou-se nas articulações entre Educação e Saúde apontando que o lugar da saúde escolar, no currículo e na vida escolar, parece seguir um caminho de disciplinamento e normalização de corpos e de espaços.

O estudo se desenvolveu por meio de pesquisa bibliográfica, fazendo uso de entrevistas realizadas com estudantes de escolas públicas, artigos publicados na Revista do Ensino² de POA/RS (1950-1960), atas do Conselho Escolar, relatórios do Serviço

\footnotetext{
${ }^{2}$ A Revista do Ensino do Rio Grande do Sul foi um importante órgão de divulgação patrocinado pela Secretaria de Educação e destinado especialmente ao magistério estadual. Seu primeiro número foi editado em 12 de setembro de 1939. A revista era autônoma e privada; não dependia de verbas orçamentárias, não recebia subvenção ou incentivos financeiros, apenas tinha uma colaboração técnico-pedagógica da
} 
Médico, imagens dos gabinetes médicos e dentários e estudos de teses e dissertações desenvolvidas sobre o presente tema.

A seguir apresentamos os três tópicos que o estudo se propôs a fazer em relação à difusão das regras de bem viver nas práticas de higiene escolar.

\section{Os discursos médicos e as práticas de higiene escolar}

Muitos estudos consistentes já foram realizados para entendermos a circulação dos saberes da Medicina no âmbito das práticas escolares, nas primeiras décadas do século XX. Entre eles, citamos a tese de doutorado de Maria Stephanou (1999) e de Heloísa Helena Pimenta da Rocha (2001). Os estudos de Dilza Pôrto Gonçalves (2013), embora não tratem especificamente do tema, apresentam atravessamentos com a temática abordada. Além disso, muitos artigos científicos servem de âncoras para o aprofundamento do tema, bem como a obra de Heloísa Helena Pimenta da Rocha, lançada em 2017, intitulada Regras de bem viver para todos, na qual, a autora, apresenta um projeto intensivo e intencional de higienização social e de educação sanitária da população brasileira, no início do século XX.

Nas primeiras décadas do século $X X$, os médicos brasileiros, especialmente sanitaristas e higienistas, foram reconhecidos como aqueles que detinham um saber "verdadeiro", e por isso, o direito de falar sobre os modos de cultivar uma vida saudável, a competência para compreender os fenômenos da vida e da doença e definir uma profilaxia e uma terapêutica, bem como a capacidade de investir o discurso acerca da saúde e higiene em decisões, instituições ou práticas (FOUCAULT, 1995, p. 74-75).

Para Stephanou (2011, p. 155), assistência médica aos escolares, inspeção médicoescolar, serviço de higiene escolar, educação sanitária, assistência sanitária à criança, medicina escolar, são expressões que assinalam variações de um mesmo tema. Permitem identificar ênfases sutis, momentos distintos, todos eles, contudo, delimitando em larga escala a relevância da escola para a medicina e a abrangência da ação médica.

Para a autora, os médicos apresentaram-se como uma espécie de mediadores, aqueles que, propondo medidas de ordenamento do espaço e purificação do meio,

Secretaria (BASTOS, 2005). 
conduziriam a uma sociedade sadia e positivamente civilizada. Dessa forma, a degeneração poderia ser contornada. A enfermidade dos corpos e da sociedade cederia lugar à saúde e à vida. Fazia-se mister, contudo, garantir espaço para a atuação educativa e saneadora da medicina (STEPHANOU, 2011, p. 148).

Nessa costura, Antonio Viñao Frago e Pedro Martínez destacam que, a partir dos finais do século XIX, os médicos-higienistas, em seu afã de debelar as epidemias, combater a mortalidade e produzir novos modos de viver em sociedade, consideraram a escola como objeto privilegiado de intervenção, dedicando-se ao estudo dos tempos e espaços de escolarização, dos métodos e procedimentos de ensino, bem como da constituição física e intelectual dos alunos (ROCHA, 2017, p. 25).

No intuito de legitimar a identidade nacional e a renovação educacional como processo civilizador constituinte do conceito de escola nova no século XX, a emergência dos discursos médicos sobre educação, desencadeou múltiplas ações no âmbito das escolas a respeito da difusão das práticas de higiene escolar.

Uma das ações instituídas foi a atuação de Sebastião Barroso, médico, jornalista e político, e um dos nomes mais representativos do movimento de renovação educacional, investido da autoridade que o cargo de inspetor lhe conferia, em vários estados brasileiros e em múltiplas iniciativas, as quais têm como sua característica mais recorrente a preocupação com a difusão e a vulgarização dos preceitos higiênicos (ROCHA, 2017, p. 31).

A obra Bibliotheca Popular de Hygiene: a saúde para todos ${ }^{3}$, de Sebastião Barroso publicada pela Cia. Melhoramentos, durante a década de 1930 trata de uma coleção composta por 22 títulos e, procura compreender os modos como se escolariza um determinado objeto cultural. A coleção é uma verdadeira iniciação popular de caráter científico, tratando da casa, desde a sua construção, dos alimentos da gestante, da prevenção contra moléstias infecciosas ou não, dos remédios, da necessidade dos exames médicos periódicos, da higienização mental e da eugenia em geral. Todos os livros vêm acrescidos de um apêndice, no qual o professor Lourenço Filho apresenta a

\footnotetext{
${ }^{3}$ A coleção Bibliotheca Popular de Hygiene foi publicada pela Cia. Melhoramentos de São Paulo em 1930 e apresentava uma série de pequenos volumes versando sobre os preceitos indispensáveis à saúde do corpo e do lar, e necessários à felicidade humana (FOLHA DA MANHÃ, 13 out. 1935, p. 21).
} 
orientação didática que o professor primário deve seguir para as suas aulas de educação higiênica (ROCHA, 2017, p. 192).

Dessa forma, os anos 1930 marcaram um importante momento na produção e na comercialização de livros voltados para o público escolar, na medida em que intelectuais, jornalistas e professores arregaçaram as mangas e puseram mãos à obra; começaram a produzir livros infantis que tinham um endereço certo: o corpo discente das escolas igualmente reivindicadas como necessárias à consolidação do projeto de um Brasil moderno (ROCHA, 2017, p. 25).

Além das obras de Sebastião Barroso, publicações veiculadas nos jornais da época sobre os anúncios de remédios para os mais diferentes males constituíam-se em impressos voltados para a difusão de preceitos higiênicos e a sua divulgação na imprensa diária.

Outra forma de disseminar os hábitos de higiene na população seria por meio das instituições escolares, atingindo não só as crianças, mas também suas famílias. Nesse viés surgem as instituições auxiliares, as quais trataremos a seguir.

\section{O surgimento das instituições auxiliares do ensino}

A criação das instituições auxiliares do ensino deu-se pela necessidade de se pensar na nova pedagogia culminando com o formativo dos alunos que vinham ao encontro da identidade nacional e da renovação educacional. As escolas deveriam contar com grupos organizados em seus estabelecimentos, fossem eles públicos ou particulares, com um propósito comum de integrar o corpo discente, estimulando, segundo Zen (2006, p. 2332), uma formação cívica, moral e intelectual por meio do exercício de "atitudes de sociabilidade, responsabilidade e cooperação" e, contribuindo, igualmente, com o processo de busca por uma identidade nacional.

Na concepção de Lourenço Filho (1969), dentro de cada escola com mais de uma classe de alunos, deveria propor-se trabalho conjunto, em auditórios, jogos e recreação organizada, clubes e associações de alunos. Estes últimos, sob a direção dos próprios alunos, discretamente orientada, denominando-se de instituições escolares, no sentido 
de grupos sociais da própria escola, considerada como uma comunidade em miniatura, para nos servirmos de uma expressão que Dewey tornou corrente.

Segundo Santos (2010), essas instituições que se dividiam em Pelotão da Saúde, Museu Escolar, Clube de Civismo, Biblioteca, Gabinetes Médicos e Dentários etc., estavam diretamente associadas à modernidade pedagógica. Essa vertente apresenta uma escola com a pretensão de estar em consonância com a ciência renovada de "práticas diferenciadas". Essas práticas associavam-se à ideia de uma escola mais dinâmica, mais moderna, mais eficiente, melhor articulada ao meio social.

Assim, no espírito da escola funcionar como uma comunidade, ela necessitava aparelhar-se para atender a nova demanda que essa iniciativa exigia. Para isso, os médicos-higienistas interferiram de maneira rigorosa no campo educacional brasileiro, reivindicando a construção de prédios escolares e a criação de novos espaços, para que uma educação digna fosse oferecida à população, evitando que as crianças e os jovens estivessem expostos aos riscos do analfabetismo e principalmente às enfermidades. Santos (2010, p. 5) também destaca que, com a criação das instituições auxiliares, a escola atenderia seguramente a nova ordem social, cultural, política e econômica da época.

Como vimos, as escolas foram estimuladas a criar instituições escolares ${ }^{4}$, que deveriam desenvolver um trabalho social em comum na escola ou para a escola, orientando-se no sentido cívico-cultural de construção da identidade nacional pela formação de hábitos e atitudes: "autoeducação, iniciativa, cordialidade, respeito mútuo, gosto pela vida ao ar livre, observação direta, pontualidade e assiduidade, dedicação ao trabalho, zelo pelos instrumentos de trabalho, sentimento de responsabilidade, de sociabilidade e de cooperação" (BASTOS, 2005, p. 217-218).

O quadro 1 apresenta as instituições escolares existentes no Rio Grande do Sul no período de 1940 a 1942.

\footnotetext{
${ }^{4}$ O Regimento Interno das Escolas Primárias do Rio Grande do Sul prescrevia que tais instituições deveriam ser "criadas de acordo com as necessidades do ensino e do meio em que funciona a escola" e "obedecer, em sua organização, às diretrizes traçadas pela Diretoria Geral de Instrução Pública”. Essas instituições teriam a finalidade de exercitar "atitudes de sociabilidade, responsabilidade e cooperação" e deveriam surgir do interesse do aluno (BASTOS, 2005, p. 216).
} 
Quadro 1 - Instituições escolares no Rio Grande do Sul (1940-1942)

\begin{tabular}{|c|c|c|c|}
\hline Nome da instituição & 1940 & 1941 & 1942 \\
\hline Caixa Escolar & 145 & 399 & 500 \\
\hline Merenda Escolar & 52 & 145 & 119 \\
\hline Círculo de Pais e Mestres & 49 & 133 & 141 \\
\hline Clube Agrícola & 11 & 73 & 119 \\
\hline Cooperativa Escolar & 9 & 44 & 62 \\
\hline Biblioteca & 4 & 259 & 268 \\
\hline Clube de Leitura & 18 & 58 & 59 \\
\hline Grêmio Cívico & - & 32 & 58 \\
\hline Liga da Bondade & - & 16 & 6 \\
\hline Pelotão da Saúde & 1 & 65 & 123 \\
\hline Clube de Ex-alunos & - & - & 3 \\
\hline Jornal da Escola & 6 & 32 & 54 \\
\hline Museu & 11 & 52 & 65 \\
\hline Grêmio Esportivo & - & 12 & 17 \\
\hline Clube Musical & - & 9 & 15 \\
\hline Liga de Boas Maneiras & - & 4 & 7 \\
\hline Grupos de Escoteiros & - & 1 & 7 \\
\hline Outras Instituições & - & 17 & 69 \\
\hline
\end{tabular}

Fonte: Relatório da Secretaria de Educação e Cultura do Rio Grande do Sul. Maio de 1943, p. 52.

A Merenda Escolar, de acordo com o Relatório de 1943, do secretário de Educação, Coelho de Souza apresenta um crescimento significativo nos três anos analisados. A merenda deveria ser composta por alimentos nutritivos, por isso era incentivada pelo Departamento Estadual de Saúde e o Serviço de Educação e Propaganda que distribuía, por meio de material impresso, orientações sobre a alimentação do escolar (7 aos 12 anos), destacando as características de subnutrição, os componentes auxiliares de nutrição, os alimentos formadores de tecidos, os alimentos energéticos, as vitaminas necessárias no crescimento e no funcionamento geral do organismo e tipos de cardápios 5 para essa faixa etária.

${ }^{5}$ O cardápio contemplava duas sugestões de cardápios divididas em primeira refeição, almoço, merenda e 
O Pelotão de Saúde, que era considerado uma instituição de caráter assistencial e higiênico, cujo objetivo principal era "levar a criança a adquirir e cultivar preceitos higiênicos dando-lhes meios para a preservação da saúde" (CENTRO DE PESQUISAS E ORIENTAÇÃO EDUCACIONAIS, 1958, p. 65), também aparece no Relatório de 1943. Bastos e Ermel (2013, p. 147) destacam que o Pelotão de Saúde também foi uma atividade incentivada pelas autoridades educacionais, e evidenciam um crescimento bastante significativo dessa instituição escolar, de apenas um em 1940, atingiram, em 1942, o total de cento e vinte e três.

Segundo Peres (2000, p. 388), o Pelotão deveria funcionar como um "verdadeiro clube de saúde", constituído pelos alunos da escola que se interessassem por tais questões, sob a responsabilidade de um professor-orientador, auxiliado por monitores (dois monitores por classe, um de cada sexo) e, se possível, com orientação de um médico. Sugeria-se o esclarecimento e o debate de problemas, tais como: socorros de urgência em caso de acidentes; como evitar resfriados; alimentação e nutrição; tuberculose; escolas ao ar livre, ventilação; os dentes; doenças e higiene de ouvidos, olhos, nariz e garganta; o uso do lenço; higiene das mãos; sono e repouso; importância da boa atitude do corpo; o alcoolismo e suas decorrências etc. Além de preleções sobre essas temáticas, a orientação era a de que se procedesse à inspeção das dependências da escola e das casas em relação à iluminação, ao arejamento, ao trabalho doméstico, aos hábitos de saúde do aluno, às atividades do sono e repouso. A partir disso, poder-se-ia orientar e prescrever formas de uma alimentação apropriada, de cuidados corporais, de trabalho etc. Uma outra atividade que deveria estar sob a responsabilidade do Pelotão da Saúde era "a determinação das condições físicas dos alunos" (CENTRO DE PESQUISAS E ORIENTAÇÃO EDUCACIONAIS, 1958, p. 66), cuja tarefa principal seria a de periodicamente

\footnotetext{
jantar. No cardápio 1: primeira sugestão (uma laranja ou uvas, prato de mingau de aveia, xícara de café com leite, duas fatias de pão integral e mel); almoço (um bife grelhado, ensopado de ervilha e cenoura, arroz e feijão esmagado, salada crua de repolho, um copo de leite, creme caramelo); merenda (um ovo passado, duas fatias de pão integral com manteiga, chá de mate e leite); jantar (sopa com hortaliças e massa, guisado simples - molho de tomate, arroz e creme de espinafre, salada de alface ou agrião, um copo de leite); no cardápio 2: primeira refeição (uma banana ou um caqui, prato de mingau de fubá, xícara de café com leite, duas fatias de pão integral com manteiga); almoço (carne e batata assada, couve à mineira, arroz e feijão, salada de agrião ou alface, com um ovo cozido, um copo de leite, uma laranja ou uvas); merenda (pão integral, marmelada e queijo, chá de mate e leite); jantar (bife com molho de tomate, pirê de batata, arroz, cenoura ao creme, salada de alface e frutas, um copo de leite).
} 
realizar o registro, através da elaboração de gráficos, do peso e da altura dos alunos que deveriam ser controlados longitudinalmente.

Na Revista do Ensino do RS (1952), um artigo foi veiculado sobre o Pelotão de Saúde do Grupo Escolar Paula Soares. O artigo informava:

Junto ao gabinete médico dentário, funciona o "Pelotão de Saúde", instituição altamente educativa, pelos princípios que tem em vista, assim como pelos meios desenvolvidos para atingir suas finalidades. De cada classe da escola é destacado um aluno e uma aluna que mais se distingam na conduta, nos cuidados higiênicos pessoais, etc. para desempenharem o cargo de "monitores". Os monitores tem ação diária sobre os colegas de classe, como sobre a sala de aula, indo seus deveres além; zelam pela conservação da limpeza do local de recreio, não permitindo que os demais lancem ao chão papéis servidos, etc. Sua vigilância se exerce, ainda, no que respeita à saúde dos outros, sendo eles os encarregados de conduzirem ao gabinete médico os que sofrem alguma perturbação em aula, atendendo os interesses dos mesmos, nas horas de recreio. (O Gabinete Médico - Dentário do Grupo Escolar Paula Soares, 1952, p. 56).

A figura 1 apresenta o Pelotão de Saúde do Grupo Escolar Paula Soares na década de 1950.

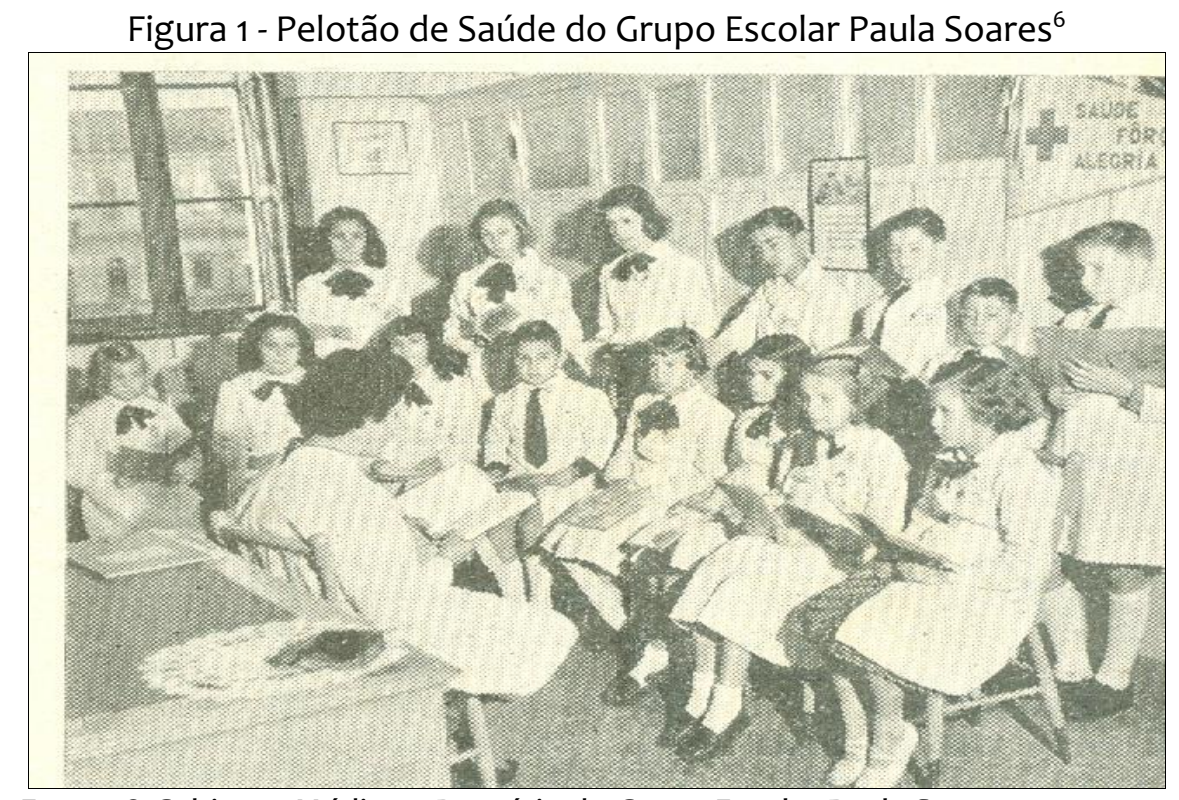

Fonte: O Gabinete Médico - Dentário do Grupo Escolar Paula Soares, 1952, p. 55.

\footnotetext{
${ }^{6}$ Na figura 1, podemos inferir que os estudantes do Grupo Escolar Paula Soares e integrantes do Pelotão de Saúde, estão recebendo as instruções das tarefas a serem realizadas, conforme consta na Revista de Ensino. O local da fotografia provavelmente seja o do gabinete médico. A professora-assistente está vestida de guarda-pó branco e os estudantes também. Ao fundo da sala aparecem cartazes, sendo que no do canto à direita consta a cruz vermelha que representa um símbolo internacional de causa humanitária, e as palavras "saúde, força e alegria”.
} 
No Grupo Escolar Uruguai de Porto Alegre, a ex-aluna Luiza destacou, em entrevista realizada, que a professora de saúde era uma espécie de monitora, e como foi escolhida para atuar no Pelotão de Saúde, sua escolha provavelmente tenha sido devido à sua aparência, as unhas bem cortadas, orelhas limpas e cabelo lavado. Luiza não se esquece do constrangimento que sentia ao ter que se colocar em uma posição de autoridade em relação aos seus colegas: "eu só brigava na hora da fila que eu queria que fizessem uma fila direita. Mas aí, teve o desfile e esse pelotão foi todo vestidinho de enfermeira, que, na verdade, era o próprio guarda-pó, só que com um chapeuzinho de enfermeira" (ALMEIDA; JACQUES; GRIMALDI, 2016, p. 251).

Quanto aos monitores, os quais são apontados no artigo publicado na Revista de Ensino sobre o Grupo Escolar Paula Soares, os mesmos possuíam uma caderneta de observações, na qual lançavam os resultados do exame geral (unhas, dentes, cabelos, indumentária, calçado etc.), que faziam semanalmente em todos os estudantes. As cadernetas eram examinadas e comentadas em reunião de todos os monitores, aos sábados, sob a orientação de uma professora-assistente do gabinete médico. Por ocasião dessas reuniões, havia também uma sessão literária na qual os temas abordados visavam a moral, a higiene física e mental, como a educação cívica - sob a forma de palestras, composições, poesias declamadas ou lidas, leitura de preceitos concernentes aos assuntos de interesse - e a citação de exemplos reais, observados pelos monitores. Além disso, organizavam álbuns ilustrados, resultados de suas pesquisas individuais ou coletivas, fazendo deles uma preciosa coletânea de todas as atividades (O Gabinete Médico - Dentário do Grupo Escolar Paula Soares, 1952, p. 55).

A emergência dos Pelotões de Saúde era produto das tendências higienistas, identificados aos princípios da medicina e atrelados à educação. Acreditamos que esse era um dispositivo peculiar dos grupos escolares daquela época, pois não foram encontrados registros da existência dos pelotões de saúde nos documentos analisados do Colégio Farroupilha.

Dessa forma, podemos pensar que a implantação dos Pelotões de Saúde por meio das instituições auxiliares estimulou e proporcionou novas formas de pensar, de sentir e de agir frente aos discursos pedagógicos e às práticas escolares principalmente da escola 
pública, no que tange aos cuidados da higiene e das práticas desenvolvidas visando o bem viver e a saúde para todos.

Podemos inferir que a década de 1940, no Rio Grande do Sul, representou um período em que a aproximação da escola com os pais dos alunos e com a comunidade, de um modo geral, foi amplamente incentivada por parte dos médicos e das autoridades governamentais. Cabia à escola funcionar como espaço de socialização e de agregação dos membros da comunidade na qual estava inserida. Nesse sentido é que o CPOE enfatizou a importância das instituições auxiliares da escola, considerando "a necessidade de socializar a escola", de promover a sua articulação com a família e a sociedade, com o intuito de atender "as novas atribuições da escola em face das contingências da vida moderna" (CENTRO DE PESQUISAS E ORIENTAÇÃO EDUCACIONAIS, 1958).

\section{Os gabinetes médicos e dentários das instituiç̧̃̃es públicas e privadas}

No Relatório de 1943, do secretário de Educação, Coelho de Souza, não constam especificados os gabinetes médicos e dentários, entretanto, podemos pensar que eles se enquadram no item intitulado "outras instituições", pois não eram todas as escolas públicas que comportavam esses serviços.

A existência dos gabinetes médicos e dentários nos leva a deduzir que era nesses espaços que a atuação dos médicos-higienistas se destacava. Além de reivindicarem a construção dos prédios escolares, pois expunham o quanto a falta de espaços e materiais higienicamente concebidos era prejudicial à saúde e à aprendizagem dos estudantes, acreditavam que dessa forma, haveria uma educação digna para a população em geral, pois evitaria as enfermidades das crianças e dos jovens. Assim, os médicos-higienistas conseguiram atingir os seus ideais tanto na esfera pública quanto na privada.

Na esfera pública, o Grupo Escolar Paula Soares7 apresentava um ambiente bastante educativo e que correspondia às normas exigidas pela pedagogia da época: o Gabinete Médico-Dentário do Grupo Escolar Paula Soares. Segundo a Revista do Ensino

\footnotetext{
7 O Grupo Escolar Paula Soares, atual Colégio Estadual Paula Soares, localiza-se no Centro Histórico de Porto Alegre, na rua General Auto, $n^{\circ} 68$.
} 
do RS, esse gabinete médico-dentário estava instalado em três salas - claras e bem arejadas - e funcionava durante todo o expediente escolar (oito horas diárias, divididas em dois turnos), servindo a todos os estudantes, sem exceção, tanto para os casos de emergências, como para os interesses de saúde, necessários ao bom rendimento do ensino, em geral (O Gabinete Médico - Dentário do Grupo Escolar Paula Soares, 1952, p. 55).

\section{A figura 2 apresenta o Gabinete Médico e Dentário do Grupo Escolar Paula Soares} na década de 1950.

Figura 2 - Gabinete médico e dentário do Grupo Escolar Paula Soares ${ }^{8}$

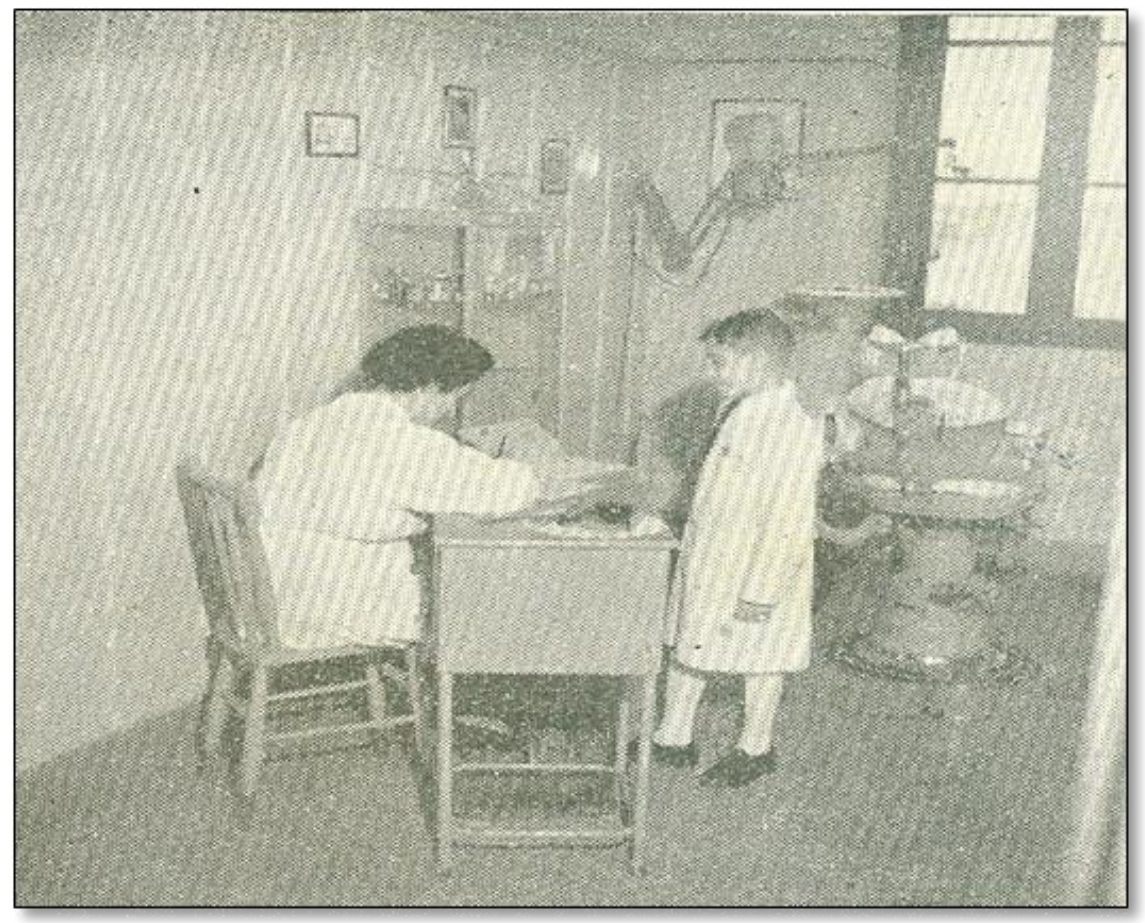

Fonte: O Gabinete Médico - Dentário do Grupo Escolar Paula Soares, 1952, p. 55.

O trabalho contava com um médico, um dentista e com o auxílio de uma educadora sanitária, duas assistentes para o serviço médico e outra para o dentário, bem como uma funcionária encarregada do serviço de limpeza e conservação.

\footnotetext{
8 A fotografia do gabinete médico e dentário do Grupo Escolar Paula Soares nos remete às práticas desenvolvidas. A figura 2 destaca a cadeira odontológica ao fundo, em frente à janela; um armário com os instrumentos de trabalho, a mesa e a cadeira. A professora-assistente veste um guarda-pó branco, assim como o estudante em pé, à frente da mesa. Na Revista do Ensino consta, em nota escrita abaixo da fotografia, a professora-assistente fazendo a ficha de um aluno.
} 
No início do ano letivo, os estudantes eram encaminhados ao exame de saúde, sendo afixados em suas respectivas fichas o peso, a altura, as condições de saúde etc. Conforme o caso, eram dispensados a cada criança cuidados especiais, orientados estes pelos resultados dos exames feitos no Serviço de Radiologia e Cardiologia, mantidos pela Secretaria de Educação e Cultura. Obtidas as licenças dos pais, as crianças eram submetidas ao tratamento no grupo escolar, com a assistência diária do médico, sempre sob verificação do aproveitamento até a completa cura almejada (O Gabinete Médico Dentário do Grupo Escolar Paula Soares, 1952, p. 55).

Paralelamente ao serviço médico, surge o gabinete dentário, e o Grupo Escolar Paula Soares, também no início do ano letivo, submetia os estudantes ao exame dentário. O diagnóstico era prescrito nas fichas contendo todos os apontamentos indispensáveis ao desenvolvimento do trabalho inerente a cada caso, ao mesmo tempo em que as crianças recebiam medicamentos recalcificantes (O Gabinete Médico - Dentário do Grupo Escolar Paula Soares, 1952, p. 55).

Ainda na esfera pública, o Grupo Escolar Uruguai, produto da fusão do Grupo Escolar da Rua Mariante e das Aulas Reunidas da Rua Ramiro Barcelos, também contemplava a existência dos gabinetes médico e dentário.

Ao conversar com alguns ex-alunos do Grupo Escolar Uruguai9, percebeu-se que suas narrativas de memórias evidenciam o tempo vivido naquele espaço. Os cinco entrevistados (Neusa, Luiza, Petronilha, Aldo e João Tadeu) lembram que havia gabinetes médico e dentário, e que os estudantes eram sistematicamente examinados e muitos recebiam orientação para tomarem a sopa da escola, possivelmente por estarem abaixo do peso adequado para a idade (ALMEIDA, JACQUES E GRIMALDI, 2016, p. 253). Neusa e Petronilha (2011, p. 154), contam que havia "um rebaixamento no teto, como se fosse um porão; não se podia passar por ali, pois logo a seguir ficava a residência - sala e quartos da zeladora chefe da escola, dona Célia, que ali morava com seus filhos". Elas contam que havia uma grande mesa, rodeada de bancos, em que era servida a sopa. Mais adiante, a cozinha com um enorme fogão à lenha, suas grandes panelas e chaleira. Em relação ao

\footnotetext{
9 Entrevistas realizadas pela Dra. Dóris Bittencourt Almeida, Me. Lucas Costa Grimaldi e Dra. Alice Rigoni Jacques em 2016, com os ex-alunos do Grupo Escolar Uruguai da década de 1950, para a realização do artigo No casarão da Rua Esperança: Memórias de estudantes do Grupo Escolar Uruguai em Porto Alegre/RS (19481954), que integra a obra Colégio Elementares e Grupos Escolares no RS., lançado em março de 2017.
} 
gabinete dentário, Petronilha salientou que o dentista aplicava flúor nos dentes e tratava as cáries.

Quanto ao Grupo Escolar Souza Lobo, Ermel, em suas pesquisas de mestrado e doutorado, trata de temas que apresentam atravessamentos com a temática sobre a circulação dos saberes da Medicina. A autora analisa essa instituição educacional que foi criada a partir do decreto n. 1.197, de 20 de janeiro de 1913, sob a designação de Colégio Elementar Souza Lobo' ${ }^{10}$. Ermel (2017, p. 206), destaca que o edifício do colégio, posteriormente denominado Grupo Escolar Souza Lobo, seguiu sob a responsabilidade da Diretoria de Obras Públicas, onde em 1955, foram localizadas algumas plantas de reformas e adaptações, entre elas a sala para jardim de infância, cozinha, refeitório, dormitório, cooperativa, secretaria, gabinete dentário, gabinete médico, sala de música e canto e sala dos professores.

A figura 3 apresenta o consultório dentário do Grupo Escolar Souza Lobo.

Figura 3 - Consultório dentário do Grupo Escolar Souza Lobo.

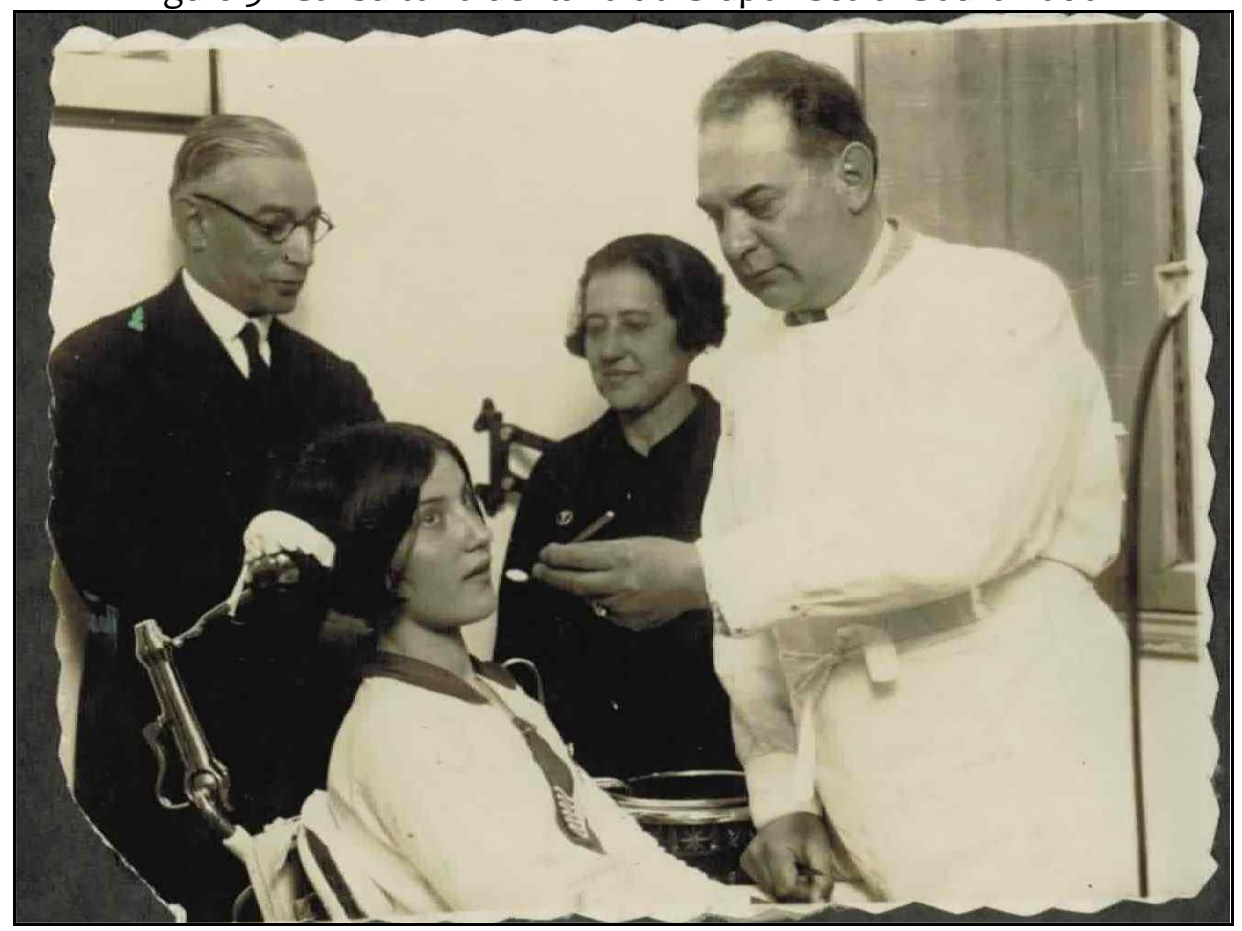

Fonte: Jornal A Voz da Escola, ano 7, n. 2, set., 1940.

\footnotetext{
10 O local onde a instituição foi instalada consistia em um terreno com 29 metros de frente, em uma edificação, de propriedade da Associação Protetora da Infância, Avenida Bahia, número 948, zona norte da Capital. Segundo o relatório da Diretoria de Obras Públicas, a instituição começou suas atividades escolares em março de 1914. Localizado no Arrabalde de São João, um bairro em pleno desenvolvimento operário no início do século XX, ao lado do Arrabalde Navegantes, que integrava uma área industrial em desenvolvimento, nesse mesmo período (ERMEL, 2017, p. 202).
} 
Ao analisar o acervo salvaguardado e preservado pela escola, Ermel identificou uma série de documentos, como: livros de matrículas e fotografias, de modo especial, sobre o período de direção de Branca Diva de Souza, que exerceu sua função neste cargo entre 1918 e 1939. Dentre imagens da diretora em companhia de suas colegas professoras, temos o registro de alunos, do edifício antigo e dois espaços internos, um deles do gabinete dentário e outro de trabalhos manuais (2017, p. 207).

Bastos e Ermel (2013, p. 150) apontam que no jornal escolar "A Voz da Escola11", de abril de 1938, a aluna Argemira Strano, do $5^{\circ}$ ano C, descreve de forma minuciosa a escola, e destaca o gabinete dentário pela sua modernidade.

\begin{abstract}
O nosso colégio
Situado no arrabalde de São João, com uma matrícula superior a mil alunos, o colégio "Souza Lobo" é um dos principais estabelecimentos de ensino de Porto Alegre. Consta de quatro pavilhões rodeados por um vasto terreno. Neste, brincamos e fazemos exercícios físicos, à sombra de velhos eucaliptos. Veem-se, no andar térreo do prédio, doze janelas gradeadas, de forma retangular. Duas escadas levam-nos ao primeiro andar. Este também apresenta doze janelas, um pouco maiores que as outras. Quase todas são gradeadas e arejadas. Estão confortavelmente mobiliadas com classes, armários, quadros negros e mesas. Nas paredes estão mapas, quadros de sistema métrico, de ciências, etc.... A biblioteca possui livros úteis e interessantes, que muito gostamos de ler. Existe no colégio um moderno gabinete dentário. Tudo isso é conservado com ordem e asseio. Gostamos do nosso colégio e, com prazer, o freqüentamos diariamente. Aqui encontramos bons colegas $e$ aprendemos muita coisa, que mais tarde, nos será útil. (A Voz da Escola, 1938 apud BASTOS; ERMEL, p. 150)
\end{abstract}

No periódico, cuja editoria pertencia aos alunos, encontram-se temas que abordam assuntos sobre regras higiênicas, entre elas os cuidados com determinados insetos e a produção de mofo. Questões ligadas ao exame médico escolar também são veiculadas nas páginas do jornal. Na edição de setembro de 1940, a seção intitulada Página da saúde, destaca esse aspecto. Segundo Bastos e Ermel (2013), o artigo principal, escrito pelo médico de higiene escolar Alfredo B. Hofmeister, inicia com a rogativa para conscientização e apoio dos pais dos alunos para o cumprimento do programa social do Departamento Estadual de Saúde. No periódico também é possível perceber a existência

\footnotetext{
${ }^{11}$ A Voz da Escola era um jornal escolar produzido pelos alunos do Colégio Elementar Souza Lobo no período de 1934 a 1940. Sobre isso, ver Bastos e Ermel (2013).
} 
do gabinete médico e dentário, pois é enfática a divulgação realizada acerca do trabalho dos médicos e dentistas frente ao atendimento aos alunos.

Essa prática desenvolvida no Grupo Escolar Souza Lobo vem ao encontro do que era proposto pelas instituições auxiliares: a escola deveria ser o local promotor da saúde, do bem-estar e do bem viver da comunidade. Investir na comunidade escolar daria condições para controlar as moléstias, garantir a harmonia social, contribuir para a formação de novas condutas nos alunos, uma vez que era objetivo naquele período integrar o corpo discente, estimulando a uma formação cívica, moral e intelectual, ou seja, moldando uma identidade nacional.

Diante do contexto nacional, as primeiras décadas do século XX foram marcadas por novas metodologias e processos escolares. Entre elas, destacamos a criação das instituições auxiliares que corroboraram a formação de um espírito nacionalista através do civismo e do amor à Pátria, bem como, desencadearam concepções e práticas pedagógicas que se voltaram para a preocupação com a saúde e a higiene.

O atraso vivido no período anterior à República, caracterizado por sujeira, feiúra, doença, ignorância, prostituição, loucura, vadiagem, morte deveria ser substituído pela representação da limpeza, do cuidado com o corpo, da higiene, da saúde bucal, da educação, da disciplina, da ordem e da produção.

Com a criação da Secretaria de Estado dos Negócios da Educação e Saúde Pública em 1935, a educação passou a ter outra significação para o Estado, fazendo com que a Escola Normal representasse um início de modernidade no estado do Rio Grande do Sul. No ano anterior, por intermédio do governador, General Flores da Cunha, foi construído um novo prédio para a Escola Normal, e no ano de 1935, a Escola Normal passou a ser designada como Escola Normal General Flores da Cunha, permanecendo assim até 1939, quando foi transformada em Instituto de Educação.

Gonçalves (2013, p. 274), ao analisar o jornal A Federação' ${ }^{12}$, localizou uma notícia veiculada em 08/06/1935, que oficializa a construção da Escola Normal General Flores da Cunha como uma obra imponente que ativaria o ritmo de progresso e incentivaria o

\footnotetext{
${ }^{12}$ A Federação foi um jornal criado para divulgar as ideias republicanas e abolicionistas. Assis Brasil escolheu o nome para o novo periódico, que circulou de $1^{\circ}$ de janeiro de 1884 até 17 de novembro de 1937 (GONÇALVES, 2013, p. 116).
} 
desenvolvimento material e cultural do estado. Dentre as obras imponentes, é ressaltado que

[...] será também das mais belas obras de arte que ostentará a metrópole gaúcha. (A Federação, 1935 apud GONÇALVES, 2013, p. 274)

[... ] A fachada, como, aliás, todo o exterior do edificio, foi realizada dentro de uma concepção estilistica em que a elegancia e a harmonia do estilo classico, evocativo da arquitetura grega, se casa admiravelmente coma as linhas de estilo moderno. (A Federação, 1935 apud GONÇALVES, 2013, p. 274)

Também recebe relevância a implantação dos gabinetes médico e dentário juntamente aos tantos outros espaços criados na instituição, como vemos a seguir:

[...] além das diversas dependências, como salas para a direção, secretaria, portaria, biblioteca, mapoteca, gabinetes de fisica e quimica, sala de leitura, salão nobre para os professores, etc. o esplendido edíficio escolar dispõe de 27 salas de aula de 8,40 x 6,80 metros. A essas salas devem acrescentar-se, além das mencionadas, o gabinete médico, gabinete dentário, gabinete de experiências psicológicas e de "tests" (grifo do autor) museu de dependencias sanitarias e quatro enormes salas de desenho e trabalhos manuais de 20 metros quadrados cada uma. (A Federação, 1935 apud GONÇALVES, 2013, p. 274)

Segundo Gonçalves (2013, p. 274), o conteúdo das notícias reforçava não só a monumentalidade do prédio, mas o pensamento da época sobre a educação relacionada às práticas de higienização. A estrutura da escola deveria atender as mais novas teorias da educação, que também eram símbolo de desenvolvimento e progresso.

Em entrevista sobre a existência de um profissional dentista na Escola Normal, a ex-aluna Elisabeth ${ }^{13}$ destaca que frequentava o gabinete acompanhada de sua mãe. No local, realizava a limpeza dos dentes com flúor. Elisabeth também salienta que a sala do gabinete era muito limpa e que o dentista mostrava como os dentes deveriam ser escovados. Sobre o gabinete médico, a ex-aluna aponta que era bastante frequentado pelos alunos para verificar o peso e a altura.

Outra instituição, porém, na vertente das escolas privadas de Porto Alegre, é o Colégio Farroupilha, escola étnica fundada por imigrantes alemães que também

\footnotetext{
${ }^{13}$ Entrevista realizada em outubro de 2020 por meio de “informação verbal”.
} 
funcionava no centro de Porto Alegre, numa sede própria construída no ano de 1895, considerada segundo Jacques e Ermel (2013), um dos primeiros edifícios escolares projetados e construídos no centro da cidade. Inicialmente funcionava a escola de meninos na pequena Rua São Raphael, $n^{\circ}$ 540. Anos depois, em 1929, é que a escola se torna mista, proporcionando escolarização para meninos e meninas no mesmo prédio. Nesse período, a escola oferecia em seu currículo o idioma do seu país de origem, a língua alemã.

$\mathrm{Na}$ final da década de 1930, surgiu a necessidade de se pensar em alternativas para a instalação de outros espaços, a fim de atender às novas exigências oriundas a partir da instalação do Curso Ginasial. São eles: salas de línguas, sala de desenho, gabinete de História Natural, Mineralogia, Física e Química, sala de Geografia, laboratório para demonstrações e trabalhos práticos e gabinete médico.

No âmbito das escolas privadas, o Colégio Farroupilha já dava indícios da criação do gabinete médico para os estudantes da escola, quando na ata da $10^{\text {a }}$ Sessão do Conselho Escolar de 08/07/1940, o Diretor Álvaro Difini informou ter adquirido, por ocasião de sua permanência na Capital Federal, a aparelhagem necessária para a instalação do Gabinete Biométrico. Na $14^{\text {a }}$ Sessão do CESBA - Conselho Escolar da Sociedade Alemã - (23/12/1940), ficou acordada a máxima brevidade na realização do exame médico dos estudantes do educandário. Para que isso se concretizasse, era necessário o encaminhamento de propostas de profissionais para o atendimento dessa demanda (Livro de Atas do Conselho Escolar do Ginásio Farroupilha, 1940).

$\mathrm{Na} 16^{\mathrm{a}}$ Sessão, O Conselho Escolar (17/03/1941) decidiu-se pelo aguardo da apresentação de propostas por parte dos profissionais interessados em assumir a assistência médico-escolar, os professores Drs. Natal Cruvinel Paiva (Curso Ginasial) e Ervino Jacob Diefenthaeler (Curso Primário). Ambos os médicos, apresentaram suas propostas em ofício encaminhado aos membros do Conselho Escolar no mês de abril de 1941 (Relatório de Inspeção do Ginásio Farroupilha, 1941).

A proposta do Dr. Ervino J. Diefenthaeler era designada para o ensino primário. No livro de atas do Conselho Escolar do Ginásio Farroupilha (1941), ele explicita as funções que desempenharia, caso fosse escolhido, para o cargo do serviço médico escolar. Nas funções descritas, destacou a realização de exames clínico-biométricos no corpo discente 
do ensino primário solicitados pelo Departamento Estadual de Saúde; a importância da parceria com os professores nas questões da aprendizagem cognitiva; o cuidado e a vigilância junto aos alunos que apresentassem anomalias funcionais ou orgânicas.

Para o curso ginasial, o Dr. Natal C. Paiva apresenta em sua proposta a execução de todas as exigências baixadas pelo Departamento Nacional do Ensino do Ministério de Educação, quanto às instruções para o serviço médico de educação física nos estabelecimentos de ensino: iniciando pelo exame clínico geral separatório entre educandos normais e deficientes, verificação da aptidão cardíaca ao esforço, novo exame clínico de todo o aluno que, durante os exercícios físicos, demonstrar medíocre comportamento em ação, novo exame clínico geral, ao iniciar-se o terceiro bimestre. Convidar os pais dos alunos encontrados não perfeitamente normais do ponto de vista da higidez, a comparecer ao ginásio para, em consulta sem ônus, obter a indicação dos meios terapêuticos. Realizar três vezes por semana uma hora de expediente médico. Fornecer todo o material clínico imprescindível à realização das exigências ministeriais (PAIVA, 1941).

A inspeção do ensino era prática corrente do governo brasileiro, tanto para instituições públicas como privadas, pois remonta ao processo de organização e expansão das escolas primária e secundária do país. De acordo com Ermel (2015, p. 97), a partir dos relatórios de inspeção do Colégio Farroupilha, podemos adentrar nas relações entre a instituição e o Governo Getúlio Vargas, destacando o empenho do Ginásio TeutoFarroupilha em continuar suas atividades, mesmo que sob o controle do Estado Novo (1937-1945). Também são verificadas as tentativas da instituição em comprovar a sua não vinculação à cultura alemã e às práticas do nazismo, inclusive com a alteração do nome para Ginásio Farroupilha.

Além da documentação anexa nos relatórios sobre matrículas, regimento, organização e disciplina escolar, certificados de nacionalidade, atestado de conduta moral dos professores e diretor, foram localizadas as plantas arquitetônicas dos espaços que compunham o prédio escolar nos anos de 1936 e 1942, nas quais o gabinete médicobiométrico está contemplado. O gabinete médico-biométrico localizava-se no $1^{\circ}$ andar do Ginásio Farroupilha e era classificado como salas especiais. 
As salas especiais referiam-se às salas de línguas, sala de Geografia, Biblioteca, sala de Trabalhos Manuais e o próprio gabinete médico-biométrico, como podemos verificar na figura 4, destacada no Relatório de Inspeção de 1942 do Colégio Farroupilha.

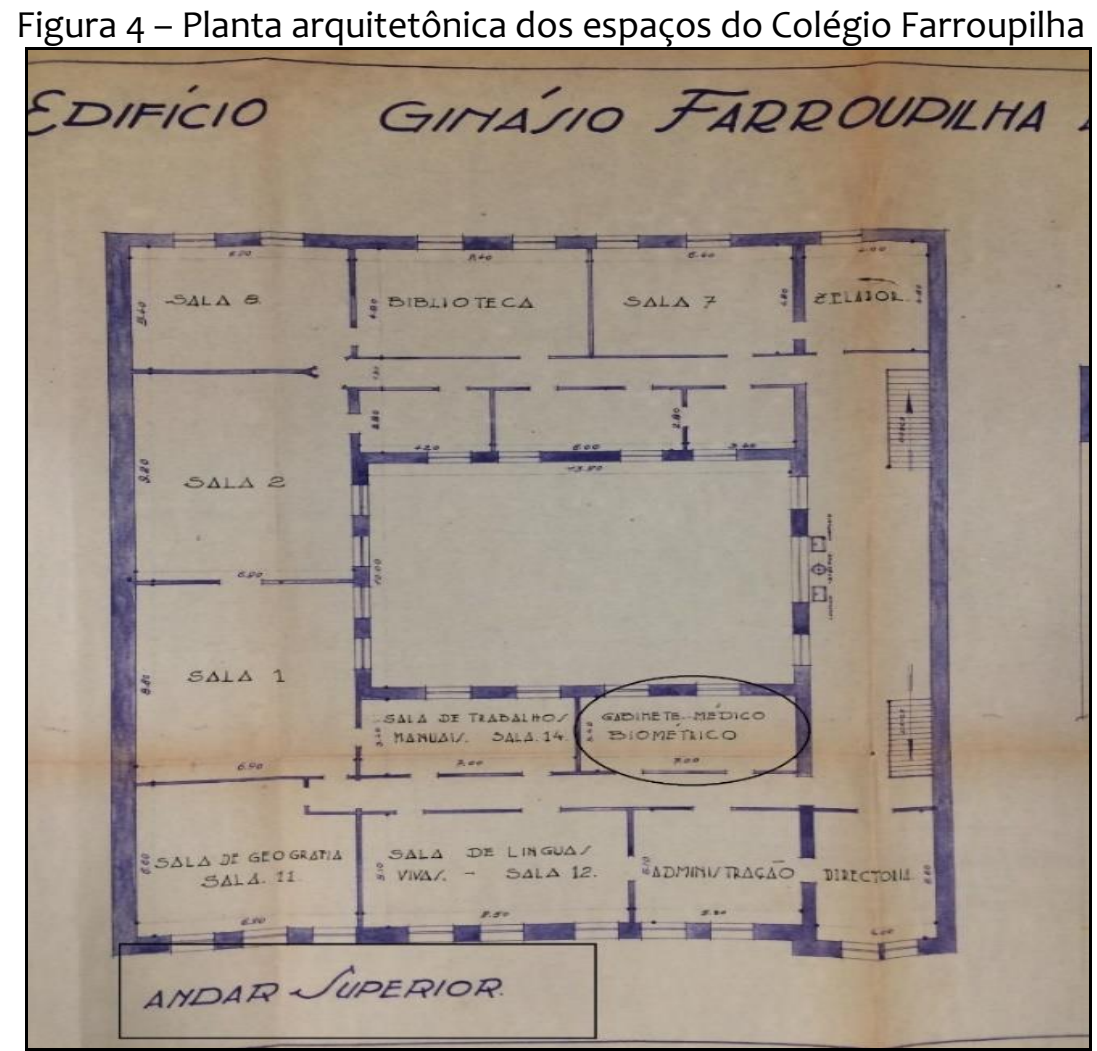

Fonte: Relatório de Inspeção do Ginásio Farroupilha, 1949, p. 75.

Nos relatórios de inspeção também foram localizados uma lista de materiais que os mesmos continham. Esses materiais estavam divididos em três categorias: exame clínico, exame biométrico e exames práticos ${ }^{14}$. O fato de o gabinete médico comportar materiais para os exames práticos (cordas, pesos, caixa para saltos etc.) provavelmente se refere à prática de exercícios físicos desenvolvidos nas aulas de ginástica.

\footnotetext{
${ }^{14}$ Materiais do gabinete médico-biométrico: Exame Clínico: 1 mesa esmaltada; cadeiras esmaltadas; armário esmaltado; 1 divan para exame e 1 armário grande para aventais de uso pessoal do médico; tesoura, pinça, algodão, ataduras, gases esterilizados; material para pequena cirurgia; álcool, tintura de iodo; mercúriocromo; amoníaco. Exame Biométrico: 1 trena; 1 cronômetro; 1 dinamômetro (força manual e lombar); 1 espirômetro de água (capacidade vital); 1 balança com dispositivo para altura; 1 quadro para medir a envergadura; 1 quadro para apurar o sentido muscular; 1 compasso metálico para diâmetros; 1 pia louçada com água corrente. Exames Práticos: 1 trena de 20 metros; sarrafos para saltos em altura; rolos de lã para a chegada de corridas; 2 pesos de 5 quilos (arremesso); cordas de 5,50m para trepar; 2 traves para exercícios de equilíbrio; 1 quadro para lançamento de pelota; 1 cronômetro; 1 caixa para saltos com serragem; 2 postes graduados, para saltos em altura.
} 
Também nos relatórios foram encontradas as atividades desenvolvidas pelo gabinete médico, bem como o número das mesmas, realizadas no período de 1949 a 1960, as quais são apresentadas no quadro seguinte:

Quadro 2 - Atividades realizadas pelo gabinete médico

\begin{tabular}{|l|c|}
\hline \multicolumn{1}{|c|}{ Atividades } & Número \\
\hline Consultas: alunos, corpo docente e pais & 179 \\
\hline Curativos sob controle médico & 29 \\
\hline Consultas para professoras & 21 \\
\hline Conferências com corpo docente e com os pais sobre & \\
questões médico-pedagógicas & \\
\hline Exames requisitados: & 04 \\
EEG & 02 \\
ECG & 03 \\
Radiografias & 14 \\
Laboratoriais & 01 \\
\hline Tratamentos realizados: & 01 \\
Hepatite Virótica & 02 \\
Gengivite Escorbútica & 04 \\
Mononucleose & 03 \\
Astenia neuro cerebral & 89 \\
\hline Visitas com médico-social & \\
\hline Exames oftalmológicos & \\
\hline
\end{tabular}

Fonte: Relatório do Gabinete Médico do Colégio Farroupilha (1942 a 1960).

A partir do quadro 2, sobre as atividades desenvolvidas pelo gabinete médico, percebe-se que as consultas realizadas com os alunos, professores e pais apresentam um número bem significativo em relação às demais atividades. Consultas com as professoras também aparecem no quadro e provavelmente diziam respeito às situações surgidas em sala de aula em relação aos seus alunos e que eram observadas por elas. Conferências e palestras aos professores e comunidade também estão inseridas nas atividades desempenhadas pelo gabinete médico. Nessas ocasiões, os médicos procuravam orientálos quanto às necessidades básicas de higiene, alimentação saudável para o escolar e as 
enfermidades comuns que os discentes enfrentavam nas diferentes estações do ano letivo. Outro item que se destaca nas atividades desenvolvidas, diz respeito aos exames oftalmológicos realizados no Gabinete Médico, nos quais os alunos eram convidados a realizar o teste de visão, por meio da tabela de Snellen, cujo instrumento verifica-se na imagem a seguir:

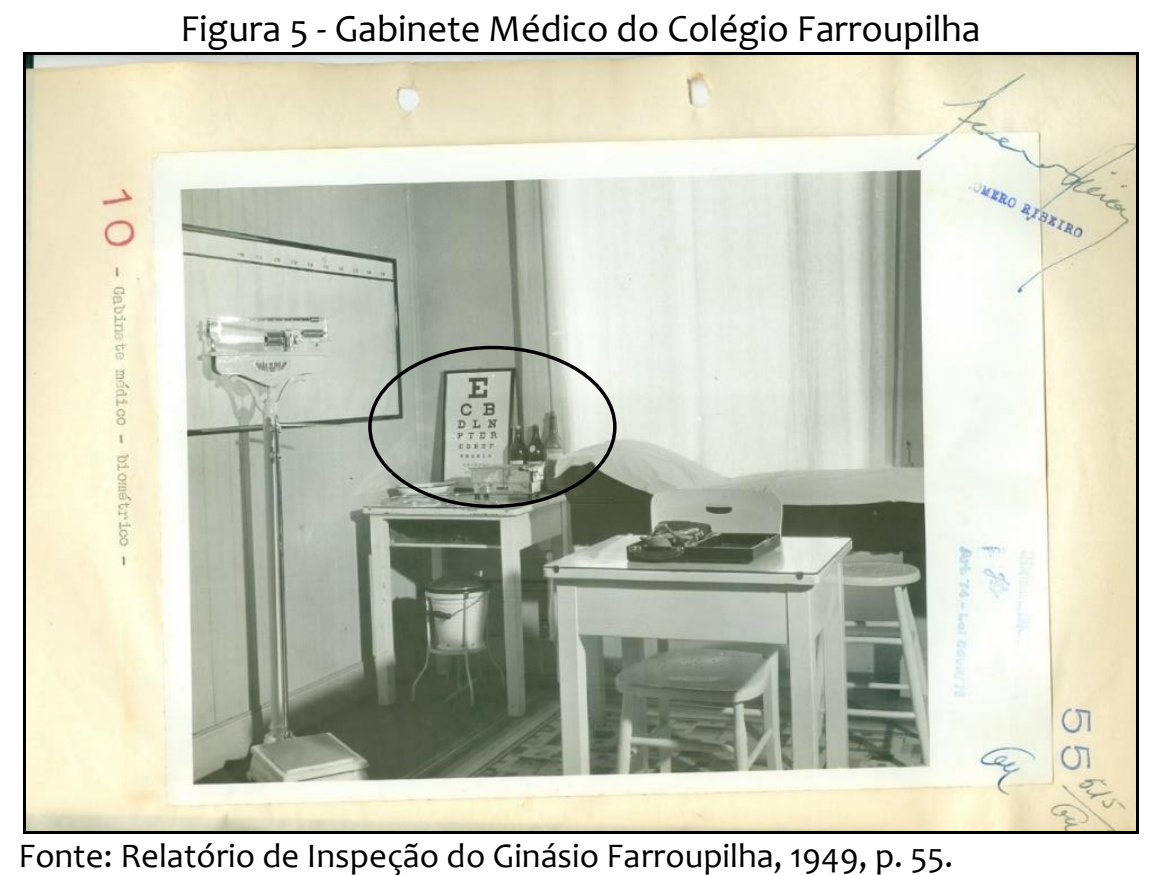

Outro procedimento realizado, complementando o serviço médico-biométrico da escola, era a abreugrafia ${ }^{15}$, um exame interno do paciente, de grande impacto, pois permitia a descoberta e a identificação de doentes que não apresentavam sintomas objetivos ou subjetivos, pelo menos evidentes, mas que eram portadores de tuberculose (STEPNHANOU, 1999, p. 152). O alto índice de mortalidade por tuberculose nas décadas de 30 e 40, e a ineficácia dos instrumentos utilizados pelas autoridades sanitárias para combater a doença propiciaram o aparecimento da abreugrafia.

Os alunos do estabelecimento eram submetidos anualmente ao exame radiológico do tórax, com abreugrafia de 70mm. Conforme visto na figura 6, no relatório de inspeção

\footnotetext{
${ }^{15}$ Abreugrafia é uma radiografia do tórax em dimensões reduzidas idealizada em 1936 pelo médico Manoel de Abreu - cujo nome integra o panteão dos indicados ao Prêmio Nobel de Medicina de 1946, 51 e 53 - e já foi exame obrigatório do trabalhador brasileiro, visando a detecção da tuberculose em indivíduos aparentemente sadios, já que a doença é assintomática, em sua fase inicial. https://www.bn.gov.br/acontece/noticias/2020/04/quem-se-lembra-abreugrafia. Acesso em: 27/10/2020.
} 
de 1949, encontramos a abreugrafia de um aluno da $2^{\mathrm{a}}$ série ginasial, cujo laudo médico realizado pelo Dr. Carlos N. Tietboehl, diagnosticava boa aparência pulmonar

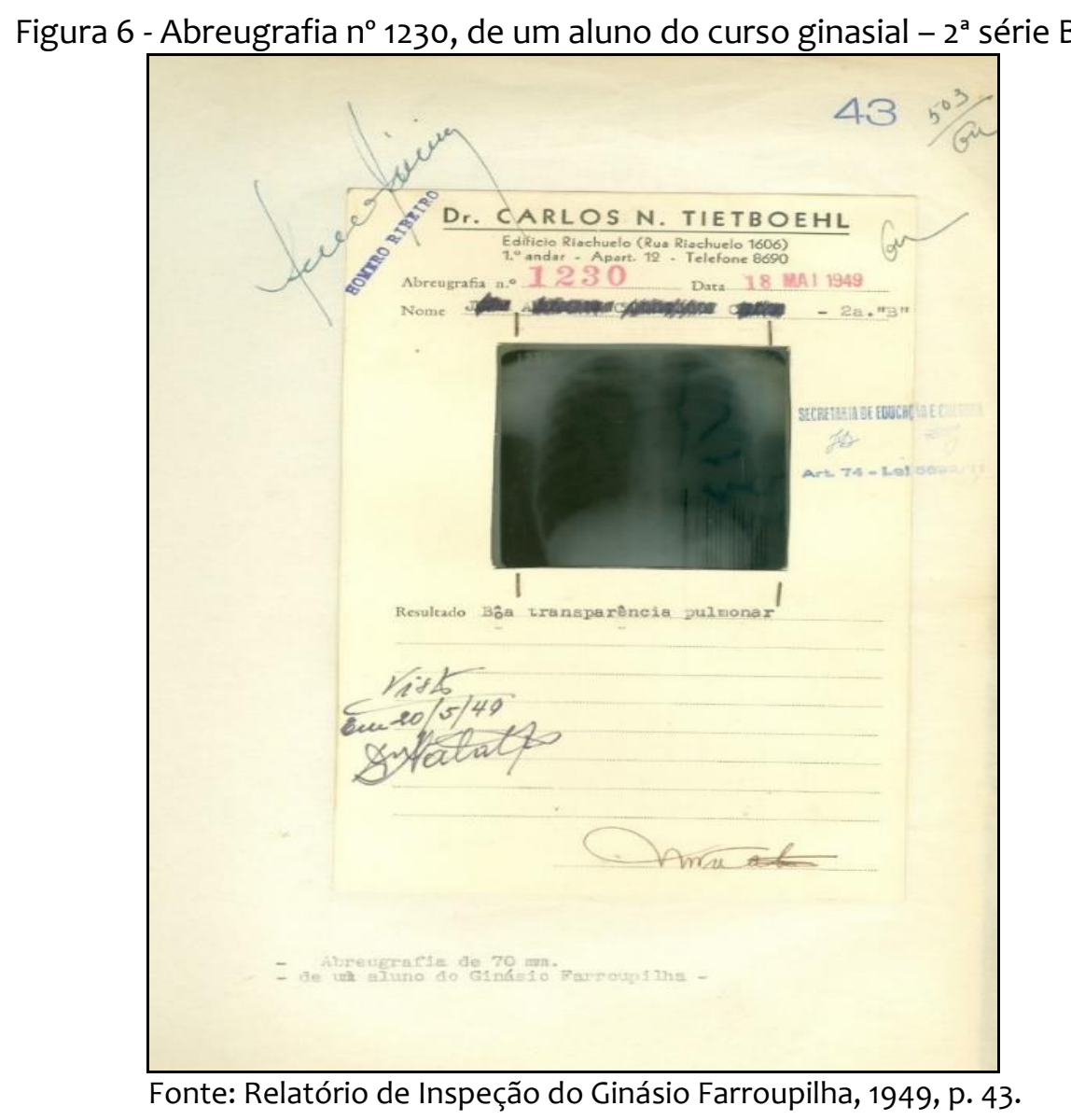

Em relação ao exame radiológico do tórax, cabe o questionamento se o mesmo era realizado também para os estudantes do curso primário, uma vez que, no relatório consta apenas uma amostragem de um estudante do curso ginasial. Sendo considerado um procedimento com excessiva dose de radiação, após alguns anos, ventilou-se a ideia de eliminar a exigência de abreugrafia para escolares, onde a incidência de tuberculose era muito baixa (GIKOVATE; NOGUEIRA, 2006, p. 109).

Baseado nos três tópicos analisados, procurou-se, de forma singular, apresentar a difusão das regras de bem viver, na década de 1930 a 1960, por meio da implantação das instituições auxiliares nas escolas, nas quais os gabinetes médicos e dentários receberam apoio das autoridades governamentais para que seu funcionamento efetivo contribuísse 
para a renovação educacional e para preparar a criança e o adolescente para viver em sociedade de forma saudável.

\section{À guisa da conclusão}

A criação e a expansão das instituições auxiliares da escola desencadeou um esforço considerável em fazer da escola um espaço de construção de uma identidade nacional, de desenvolver um sentimento de pertencimento, de controle das vontades, de garantia da harmonia social. Os Pelotões de Saúde, os Gabinetes Médico e Dentário, aqui analisados, foram algumas das formas de disciplinamento e de regulação de comportamentos e atingiram professores e professoras, médicos-higienistas, comunidade escolar, pais e, muito especialmente, a "nova geração dos brasileiros": os alunos e as alunas das escolas públicas e também das instituições privadas, como é o caso do Colégio Farroupilha.

A partir dos três tópicos analisados: a participação dos médicos no desenvolvimento e conscientização das práticas de higiene, a criação das instituições auxiliares nas escolas e dos gabinetes médicos e dentários, podemos inferir que estes foram prerrogativas da nova pedagogia e da Escola Nova. Dentro do movimento da Escola Nova e da Nova Pedagogia a presença dos gabinetes médicos e dentários nas escolas auxiliou no processo de difusão do higienismo, trazendo várias iniciativas voltadas para a educação da população, as quais incidiram, em grande medida, sobre a instituição escolar e os sujeitos da escolarização.

A confluência entre a medicina, a higiene e a educação escolar mostrou-se inevitável, pois a escola se apresentava como um espaço social por meio do qual era possível tanto garantir a atenção médico-higiênica à infância, como intervir nas famílias, reorientando suas práticas cotidianas de cuidado e educação das crianças. O cuidado com a saúde, pautado pela nova pedagogia passou a ser visto como fator decisivo na regeneração da população, já que, por meio dele, se acreditava ser possível assegurar a aquisição de hábitos saudáveis desde a mais tenra infância. A presença dos médicos e dentistas reforçou o papel da escola na prevenção das doenças, tanto pela sua ação 
direta sobre as crianças, como pela influência indireta sobre as famílias, reorientando as suas práticas cotidianas de cuidado com o corpo, a casa e a criação dos pequenos.

A partir do presente estudo, podemos considerar que os médicos-higienistas aliados às instituições de ensino foram os mentores da propagação da educação sanitária e de assistência à saúde dos educandos e de suas comunidades, e essas estruturas ou dispositivos contemplaram suas ações, preservando também nas escolas, o que era propagado no lar.

A implantação das instituições escolares é resultado da influência da Escola Nova, surgindo como um dispositivo para a nova configuração arquitetônica e a modernização da escola emergida ainda no período republicano, quando à escola coube papel fundamental na construção do "homem-novo" que as transformações político-sociais e principalmente econômicas requeriam.

A criação das instituições auxiliares nas escolas, mais propriamente dos pelotões de saúde e dos gabinetes médicos e dentários tratados neste estudo, se dá no final da década de 1930, e atingem seu apogeu nos anos 1950, principalmente nas instituições do centro urbano, cujos prédios apresentavam uma arquitetura monumental, no qual a modernidade estava acompanhada do discurso da retórica dominante. Sendo assim, o grupo escolar Paula Soares, a antiga Escola Normal General Flores da Cunha (atual Instituto de Educação) e o educandário do Colégio Farroupilha estavam localizados na área urbana da cidade de Porto Alegre. Destaca-se que o Grupo Escolar Paula Soares, a Escola Normal e o Colégio Farroupilha apresentavam uma edificação mais suntuosa. Essa arquitetura escolar magnificente evidenciava à população a ideia de privilégio e excelência do modelo escolar da época.

Já o Grupo Escolar Uruguai funcionava num casarão cercado de jardins, e estava localizado em uma região ainda com traços rurais, numa colônia africana, na qual os casebres da população negra contrastavam com chácaras e palacetes. Entretanto, com o processo de urbanização, pouco a pouco, os negros foram sendo deslocados para áreas mais periféricas da cidade e, à medida que o século XX avançou, novos grupos étnicos ali se estabeleceram, especialmente a colônia dos judeus (ALMEIDA; JACQUES; GRIMALDI, 2016, p. 238-239). Da mesma forma, o Grupo Escolar Souza Lobo, estava situado no arrabalde de São João e compreendia quatro pavilhões rodeados por um vasto terreno. 
Isso nos leva a deduzir que tanto o Grupo Escolar Uruguai como o Grupo Escolar Souza Lobo, eram, originalmente, instituições localizadas nas periferias e áreas afastadas, e não apresentavam a estrutura arquitetônica majestosa das escolas situadas no centro urbano.

A implantação dos gabinetes médicos e dentários nas escolas estava diretamente associada à modernidade pedagógica, pois envolveu as iniciativas higienistas, atestando um incremento da intervenção estatal no campo da educação e saúde públicas, que sem dúvida, colaborou para uma reforma de hábitos relacionados à higiene e à educação do corpo, e o Colégio Farroupilha, por ser uma instituição privada e mantida por empresários alemães da cidade de Porto Alegre, também privilegiava essas práticas diferenciadas.

Essas instituições, não somente os Gabinetes Médicos e Dentários, os Pelotões de Saúde, a Liga da Boa Vontade, a Merenda Escolar, a Liga das Boas Maneiras, os diferentes clubes criados dentro das instituições de ensino, refletiram, em primeiro lugar, o esforço em modernizar a escola. As atividades pertencentes a esse processo estavam diretamente vinculadas ao movimento renovador, como também a uma subjugação do corpo discente e docente a uma ordem estabelecida e imposta nas formas de pensar, de agir e de viver.

Por fim, sabemos que a grande maioria das escolas públicas funciona em péssimas condições físicas, não apresentando mais a monumentalidade arquitetônica daquela época. Quanto aos gabinetes médicos e dentários, provavelmente deixaram de existir, e os aparatos técnicos que os compunham foram destinados ao descarte ou transformados em peças obsoletas guardadas ou atiradas num canto qualquer da escola.

Quanto ao Colégio Farroupilha, por ser uma escola privada, manteve o serviço de assistência médica até o ano de 2010, com a presença de um médico escolar nas suas dependências. A partir desse período, a escola mantém em sala própria o ambulatório espaço em que são realizados pequenos atendimentos, além de promoção de palestras e atividades ligadas aos cuidados com a saúde. A equipe é composta por enfermeira e técnicas de enfermagem. 
ALMEIDA, Dóris Bittencourt; JACQUES, Alice Rigoni: GRIMALDI, Lucas Costa. No casarão da Rua Esperança: memórias de estudantes do Grupo Escolar Uruguai em Porto Alegre/RS (1948-1954). In: GRAZZIOTIN, Luciane Sgarbi Santos; ALMEIDA, Dóris Bittencourt (orgs.). Colégios elementares e grupos escolares no Rio Grande do Sul: memórias e cultura escolar - séculos XIX e XX. São Leopoldo: Oikos, 2016. p. 236-259.

BASTOS, Maria Helena Câmara. A Revista do Ensino do Rio Grande do Sul (1929 -1942): o novo e o nacional em revista. Pelotas: Seiva, 2005.

BASTOS, Maria Helena Camara; ERMEL, Tatiane de Freitas. História da Educação (online). O Jornal A Voz da Escola: Escritas dos alunos do Colégio Elementar Souza Lobo (Porto Alegre/RS, 1934-1940), Porto Alegre, v. 17, n. 40, p. 143-173, maio/ago. 2013.

ERMEL, Tatiane de Freitas. O processo de reconhecimento do Ginásio Teuto-Farroupilha: Os relatórios de inspeção federal (1937-1962). In: BASTOS, Maria Helena C.; JACQUES, Alice Rigoni; ALMEIDA, Dóris Bittencourt (orgs.). Do Deutscher Hilfsverein ao Colégio Farroupilha/RS: memórias e histórias (1858-2008). Porto Alegre: EDIPUCRS, 2015. p. 95113.

ERMEL, Tatiane de Freitas. Arquitetura escolar e patrimônio histórico-educativo: os edifícios para a escola primária pública no Rio Grande do Sul (1907-1928). Porto Alegre: PUCRS, 2017. (Tese de doutorado).

FOUCAULT, Michel. A arqueologia do saber. 4. ed. Rio de Janeiro: Forense Universitária, 1995.

GIKOVATE, Febus; NOGUEIRA, Diogo Pupo. Abreugrafia sistemática em massa: inviabilidade econômica e eventuais perigos da exposição a radiações. Rev. Saúde Pública [online], São Paulo, v. 40, n. 3, p. 389-396, 2006.

GONÇALVES, Dilza Pôrto. A instrução pública, a educação da mulher e a formação de professores nos jornais partidários de Porto Alegre/RS (1869-1937). Porto Alegre: PUCRS, 2013. (Tese de doutotrado).

JACQUES, Alice Rigoni; ERMEL, Tatiane de Freitas. O velho casarão: um estudo sobre o Knabenschule des Deustches Hilfsverein/Colégio Farroupilha (1895-1962). In: BASTOS, Maria Helena Camara; JACQUES, Alice Rigoni; ALMEIDA, Dóris Bittencourt (org.). Do Deutscher Hilfsverein ao Colégio Farroupilha/RS: memórias e histórias (1858 - 2008). Porto Alegre: EDIPUCRS, 2013. p. 92-110.

LOURENÇO FILHO, M. B. Introdução ao Estudo da Escola Nova. 10. ed. São Paulo: Ed. Melhoramentos, 1969.

PERES, Eliane Teresinha. Aprendendo formas de pensar, de sentir e de agir: a escola como oficina da vida: discursos pedagógicos e práticas escolares da escola pública 
primária gaúcha (1909 - 1959) 2000. (Tese Doutorado em Educação) Universidade Federal de Minas Gerais, Belo Horizonte, 2000.

ROCHA, Heloísa Helena Pimenta. A higienização dos costumes: educação escolar e saúde no projeto do Instituto de Hygiene de São Paulo (1918-1925) 2001. Tese Doutorado em Educação - Faculdade de Educação, Universidade de São Paulo, São Paulo, 2001.

ROCHA, Heloísa Helena Pimenta. Regras de bem viver para todos: A Bibliotheca Popuylar de Hygiene" do Dr. Sebastião Barroso. Campinas: Mercado das Letras, 2017.

SANTOS, Luciano Rodrigues dos. O médico-higienista e a arquitetura escolar no Brasil sob o prisma da educação sexual entre os séculos XIX e XX. Scientia Plena, [Sergipe], v. 6, n. 3, p.1-12, 2010.

STEPHANOU, Maria. Tratar e Educar: discursos médicos nas primeiras décadas do século XX, 1999. Tese Doutorado em Educação - Faculdade de Educação, Universidade Federal do Rio Grande do Sul, Porto Alegre,1999.

STEPNHANOU, Maria. Discursos médicos e a educação sanitária na escola brasileira. In: STEPNHANOU, Maria; BASTOS, Maria Helena Camara (orgs.). Histórias e memórias da educação no Brasil: vol. III - Século XX. 4.ed. Petrópolis: Vozes, 2011. p. 142-164.

TOTTA, Mario. Abertura dos cursos: preleção proferida. Revista dos cursos, Porto Alegre, v. 21, p. 39-42, 1935.

ZEN, Mariane Werner. Brasileiros pelas letras: atividades de associações auxiliares da escola no Grupo Escolar Alberto Torres (1941-1959), Brusque - SC. VI CONGRESSO LUSOBRASILEIRO DE HISTÓRIA DA EDUCAÇÃO: Percursos e Desafios da Pesquisa e do Ensino da História da Educação. Anais... Uberlândia, MG, 2006.

CENTRO DE PESQUISAS E ORIENTAÇÃO EDUCACIONAIS. Secretaria de Educação e Cultura. Rio Grande do Sul. Boletim do CPOE. Rio Grande do Sul: CPOE, 1958.

FOLHA DA MANHÃ (1935). São Paulo, out. Disponível em: http://acervo.folha.com.br Acesso em: 07/05/2019.

LVRO DE ATAS DO CONSELHO ESCOLAR DO COLÉGIO FARROUPILHA, Porto Alegre, 1940.

LVRO DE ATAS DO CONSELHO ESCOLAR DO COLÉGIO FARROUPILHA, Porto Alegre, 1941.

RELATÓRIO DE INSPEÇÃO DO GINÁSIO FARROUPILHA, Porto Alegre, 1941, p. 1- 130.

RELATÓRIO DE INSPEÇÃO DO COLÉGIO FARROUPILHA, Porto Alegre, 1949, p. 1-134.

RELATÓRIO DO GABINETE MÉDICO DO COLÉGIO FARROUPILHA, Porto Alegre, 1942 a 1960, p. 1 a 55. 
RELATÓRIO DA SECRETARIA DE EDUCAÇÃO E CULTURA DO RIO GRANDE DO SUL. Maio de 1943 , p. 52.

O GABINETE médico - dentário do grupo escolar Paula Soares. Revista do Ensino do Rio Grande do Sul, Porto Alegre, ano I, n 6, p. 55-56. Maio. 1952.

Recebido em: 28/05/2019

Revisões requeridas em: 06/04/2021

Aprovado em: 12/05/2021

Universidade do Estado de Santa Catarina - UDESC

Programa de Pós-Graduação em Educação - PPGE

Revista Linhas

Volume 22 - Número 50 - Ano 2021

revistalinhas@gmail.com 